\title{
The Effect of Milieu Therapy towards Knowledge of Caregivers and Relaps Response Patients Mental Disorders in Hospital
}

\author{
Nurdiana Siahaan, Omi Haryati*, Nurhalimah \\ Mental Health Department Health Polytechnic Ministry of Health Jakarta 111 \\ Jl. Arteri JORR, Jati Warna \\ *Corresponding author's email: omi.haryati [AT] yahoo.co.id
}

\begin{abstract}
Patients with mental disorder need regularly strong support system from their surroundings, one of the support system that most closely is the family including the parents and other people that live together with the clients. Knowledge of Caregivers about carrying patients with the mental disorders is very important. Sometimes they faced some troubles because lack of knowledge how to care patient with the mental disorder, This research aim is to know the effectiveness of milieu therapy toward Caregivers knowledge, attitudes, and the response of the recurrence for patients with mental disorder. The research methodology used a quasi-experiment pretest and posttest design. Using by purposive sampling 35 respondents were involved in this study. The research took place in Jakarta, Indonesia. The results of research is that the knowledge of caregiver before and after the intervention of the very means where the $P$ value, 0.000 , There is no difference about attitude caregivers before and after the intervention towards occurence with $P$ value is 0,402 , There is a difference before and after intervention of caregiver to the patient for doing milieu therapy with p-value 0.000. Conclusion: Milieu therapy made the patient with mental disorder having activities in their daily living, so there is no time for thinking the past days that made recurrence.
\end{abstract}

Keywords—-Milieu therapy, knowledge, attitude, recurrence

\section{INTRODUCTION}

The In 2002, it was estimated that 450 million people around the world had a mental disorder, about $10 \%$ of adults had a mental disorder at this time and $25 \%$ of the population were expected to experience mental disorders at a certain age in their lives. This age usually occurs in young adults between the ages of 18-21 years. Basic health research, [1] Indonesia 's population experienced $14.1 \%$ from mild to severe mental disorders. Behavioral changes experienced by people with mental disorders are very varied such as listening to whispers that are not clear origin, withdrawing, raging and hitting those around the environment, feeling afraid of something normal for normal people, and having emotions that are easy to change. People who have emotional, physical and social well-being who can fulfill life responsibilities, function effectively in daily life and are satisfied with their interpersonal and self-relationships are people who have mental health [2]. Someone who called a person have mentally healthy when fulfilling criteria such as positive attitudes toward oneself, integration, and emotional responsiveness, autonomy and self-stability, accurate perception of reality, and environmental health and social competence [3] Basic health research [ 1] states that $14.1 \%$ of Indonesia's population experience mild to severe mental disorders. Behavioral changes experienced by people with mental disorders are very varied such as listening to whispers, seeing some kinds of weird thing, withdrawing, raging and hitting those around the environment, feeling afraid of something, and having unstable emotions.

One of the causes of patients being taken to mental hospitals is violent behavior. Violent behavior is an individual's behavior that is intended to injure itself or harm other individuals. If this problem is not addressed properly, it can be able to harm patient self, others, and the environment[4] Milieu means environment, milieu therapy means effectively using the social environment as part of treatment. The purpose of environmental therapy or milieu therapy is to develop self-esteem, improve the ability to connect with others, increase the attitude of trust in others, prepare to return to society and achieve positive change.[3].

The implementation of milieu therapy in Aceh mental hospital found that milieu therapy was one of the therapies that restored patients in addition to drug therapy [5]

By using milieu therapy constantly will increase opportunities for patients to learn, improve skills and personal responsibility [6] Nurses believe that milieu therapy is modality to improve hospital service regarding to relieve mental 
health disorder as soon as possible [7] The stress of Caregiver always increase when the patient feeling unnoticed. anger, wondering, and don't want to take the medicine.[9] Patients need companions directly involved in their daily living such as giving them reinforcement when they have done something good, warmth and a little criticism Milieu therapy uses all aspects of the environment as a therapeutic tool. Starting from the people, resources and activities that exist in the patient's environment aims to improve the optimal function of the patient, interpersonal growth and the process of adaptation to life outside the hospital [10] Milieu therapy is often called therapeutic milieu which means a healing environment [11] Relapse is a patient's condition where the same symptoms appear as before and the patient need to be treated again [2]. Recurrence response is a sign or symptom that the condition of the patients is the same as before when the patient does not get the right activity therapy as milieu therapy and the medicine for mental disorder. Signs and symptoms of relapse need to be considered by the family are the patients will withdraw from the environment: selfisolation, having no brave to eye contact, clock their self in the bed room, ignore self-care, do not want to take a shower, let dirty hair, dirty nails and are not treated, Strange and unusual behavior such as talking and laughing alone , Hearing sounds that have no source, strange ideas or thoughts, Sleeplessness, more awake at night, pacing and doing things that are not clear [13] Emotions change, irritability, fear and anxiety, worry at all times, Difficult to concentrate, easy to forget, Feelings of fear of other people.

\section{METHODS}

All Research Design This study was a quasi-experimental pre-posttest. Researcher measured the stress of patients' condition before and after treatment. Population and Sample

The population of this study was the Caregivers or family with the family members who have been treated at the Regional Hospital Polyclinic in East Jakarta3. Samples

The sample appearance technique used is purposive sample. By using the formula

$\mathrm{n}=2 \alpha^{2}(\mathrm{Z} 1-\alpha+\mathrm{Z} 1-\beta)^{2}$

$(\mu 1-\mu 2)$

By using a 95\% confidence level and the strength of the $90 \%$ trial, it is estimated that the difference in mean 3 has already been significant, so that 33 respondents and anticipating drop out plus $10 \%$ are the number of research samples 37 people Inclusion and exclusion criteria

a. Inclusion criteria:

1). Family of psychiatric patients with mental disturbance

2) Regularly taking medication

3). willing to be a respondent

4). Man and woman

5) Always present at every intervention b. Exclusion criteria:

1). Not willing to be a respondent

2) Disrupted of medicine

3). Not present at the time of one of the interventions3. Data collection tool:

Data collection was carried out by using interview guidelines, observation sheets and questionnaires as research instruments as follows:

a. Demographic data instruments are instruments that are used to obtain data on the

characteristics of respondents

b. The research instrument was used to measure cognitive and psychomotor abilities of

environmental therapy before and after intervention

c. Observation sheet to find out the patient's recurrence response

4. Pilot project of the Instrument

Instrument testing is used to determine whether the data collection tool is valid and reliable before the instrument is used. Validity test uses Person Product Moment while for reliable is obtained when Cronbach's coefficient - alpha is greater than the r-table value.

5. Environmental Therapy Work

a Pre Test:

- Researchers provide questionnaires that contain environmental therapy question to the caregivers for before and after intervention.

- For patients asked care giver for the past 4 months how many symptoms of mental disorders experienced by the patient were taken to the Mental Hospital b. Treatment (Intervention)

1. Researchers provide knowledge to the intervention group about environmental therapy, the kind of activity of milieu therapy. that is therapy that uses activities at leisure with the aim of patients being able to do activities constructively and pleasantly and develop social relations skills and art therapy, such as dance therapy, music therapy, reading therapy and pet therapy, this therapy aims is to stimulate the response of patients who are unable to make interaction with people and patients who are usually lonely. 
2. Care giver who has been given the knowledge of environmental therapy will be taught to his family member who suffers with mental illness. the researcher visit them to observe which environmental therapy is given by caregivers, whether it is a therapy plant, pet therapy, music therapy or dance therapy which will certainly be adjusted to the situation and condition of both care giver and family members who experience mental disorders.

3. Patients with mental disorder will have activities every day that will make to make themself with positive thoughts such as how to get the plants will produce the results of their works so that their responses such as lack of confidence, withdrawing from the environment, have no brave to make eye contact with the other person, daydreaming or even hearing voices will slowly fade, and the patient will return to the real world. c. Post Test

After giving intervention, the researcher observed by home visited to the respondent home, the researcher gave questionnaires to the intervention group , then the data was coded, entered and analyzed.

Patients were asked to care giver for the past 4 months how many symptoms of mental disorders experienced by patients after being given milieu therapy by the family facilitated by researchers.

b. Data analysis.

Data analysis used in this study is:

1. Univariate Analysis

This analysis is used to obtain general description, gender, parenting style, economic factors of parents and number of visits to mental hospitals

2. Bivariate analysis

This analysis is used to determine differences in the level of knowledge of parents before and after being given milieu therapy by using $t$ test pair and knowing the differences in the control group and intervention group through Independent Test

\section{RESULTS}

This research aims to find out the influence of the milieu therapy against the level of knowledge of the care giver and the response of the recurrence in patients with the soul with design research is a quasi-experiment with pre and post the number of respondents is 35 respondents.

Respondent characteristics of the aspects of the age show that the age of the care giver that most young people are aged 17 years. Economic factors (income) patients still more dominate on the level below. Respondent education starting from elementary school (5.7) to college (11.4) UMR Per namely: 51.8\%. The knowledge of the patient prior to intervene about milieu therapy has the spread of the low as much as 27 people $(71.1 \%)$, is 4 people $(11.4 \%)$ and high 4 people $(11.4 \%$,) while for the attitude of care giver willing to teach about the activities of the milieu therapy is 25 people (71.4\%) and reluctant to teach ten people (for 28.6). Signs and symptoms that are still on patients with the soul that is obtained from the care giver is to risk of recurrence small is $19(54.3 \%)$ and the risk of recurrence is 16 people (45.7\%). The level of knowledge about the milieu patients after therapy has been intervened experience changes where the low level of knowledge to low, level is 1 people ( $2.9 \%$ ) and high 34 people (91.7 5\%) for care giver attitude after getting instruction/training on the material milieu teach therapy to $29(82.9 \%)$ people ( $91.7 \%)$ and reluctant to teach 6 people ( $17.1 \%$. The level of knowledge of the care giver before given mean intervention is 3.91 and after given the intervention Mean 14.17 with the difference in mean : 10.26 with P-value : 0,000.. Symptoms of occurrence the respondents before giving milieu therapy is 7.83 and after being given milieu therapy is 2.11 with mean differences is 5.72 and P-value 0.000 , There is no differences about attitudes care giver before and after given milieu therapy toward to patient mental disorder.).

\section{DISCUSSION}

Primary From the analysis results variant union found that respondent or care giver relationship with the patient is the family of the father, mother, the husband, sisters, brothers and children. There is no one of the respondents from outside the family or other people who are employed as a care giver: $0 \%$, Family is a group of two or more people who live together with rules and emotional bind by blood and emotional and having the rule of each part. In this case it was proofed that the caregivers were the family member.

The results of the study showed that the education is the most senior high school as many as 22 respondent $(62.9 \%)$ Education is the learning process which means that happened, the process of growth, development or changes toward more adult better and more mature on the individual and the family and the community. Education is important in order to provide assistance to the development of the individual, so that they can understand the communication, information and education with good [11]

Respondent education starting from elementary school to college, there is no difference whether a education is high or low is not willing to be a care giver, the higher the level of caregivers education, the better mentoring which is given to patients. Because the medicine and therapy given to patients with the mental disorder quite complex. Patients are not willing to drink drugs with various reasons, some say sleepy continue, or bitter that they hide their cures under the tongue, It nee $\mathrm{d}$ to higher education to explain to patients that drugs that drink cannot be disconnected, because it will result in treatment that is not perfect and the patient to be long to recover.[12] . Income is one of the economic factors 
that affect the accuracy of the patient when the control to the hospital the mental disorder.

The characteristics of respondents of gender in this research is still dominated by women: $65.7 \%$, women have a nurturing nature which makes them feel more responsible and full attention to the family experience of the soul trouble [2], besides the nature of women is filled with compassion with its role as a flavoring safe and comfortable on his family.[4].

The knowledge of the respondents about therapy milieu or environment therapy before intervention shows that the respondents do not know about the therapy milieu even though their family members are experiencing the mental disorder by years, this can be understood because usually only health officials provide treatment to the patients [14]. To reduce the patients relapse the patients should have routine activity by establish schedule for indication that they always do something every day.

The importance of creating the schedule for patients in the conduct of therapy milieu activities will make patients continue to perform the activities so that there is no time for patients to return to the isolation behavior especially when patients medication regularly and that side effect is drowsiness, patients must be explained that at the time of the medication, emotions and his mind was calm and controlled at the time of this is the right time to patients defeat Paul continued by doing activities that means with assisted or supported by the family to pay attention and affection.[9] so that the symptoms recurrence patients decreases. Recurrence is the return of the sign - signs and symptoms of disease after a restoration would occur and result in patients treated return [10]. Preventing recurrence on patients with mental disorder is a regular activities, concern activities daily activities of patients, give praise if patients were successfully medication regularly and independently, regularly with the support of the family control.

With regular activity and medication that sustainable and not failure, the patients can perform the activities such as the other normal, only the family must often invites patients in discussions about the patients experienced during he worked something, so that when there are factors that make the patient to be stress can be discussed and search for the way out where care giver only facilitates after the patients unaware of what is happening let the patient take the conclusion of the cause of his stress and be aware of the existence of the status of her emotions. Some symptoms of recurrence indicated the patient is changes such feelings as anxiety, fear, irritable, feel sad, not happy. The change of mind like many think or confused, difficult decision or pessimistic negative-minded. Changes in behavior no interest, lazy bath, want to continue to sleep, anxiety could not sleep, then one his way managements is to bring the patient to a doctor to get treatment therapy. after the patients calm and environmental therapy can be given the care giver is scheduled so that the symptoms of recurrence patients will be reduced

\section{CONCLUSION}

With regular activity and medication that sustainable and not failure, the patients can perform the activities such as the other normal, only the family must often invites patients in discussions about the genesis - genesis experienced patients during he worked as anything, so that when there are factors that make the patient to be stress can be discussed and search for the way out where care giver only facilitates after the patients unaware of what is happening let the patient take the conclusion of the cause of his stress and be aware of the existence of the status of her emotions. Some symptoms of recurrence indicated the patient is changes such feelings as anxiety, fear, irritable, feel sad, not happy. The change of mind like many think or confused, difficult decision or pessimistic negative-minded. Changes in behavior no interest, lazy bath, wants to continue to sleep, anxiety could not sleep, then one2his way managements is to bring the patient to a doctor to get treatment therapy. after the patients calm and environmental therapy can be given the care giver is scheduled so that the symptoms of recurrence patients will be reduced

\section{ACKNOWLEDGEMENT}

This study has been approved ethical clearance from Health Polytechnics Ministry of health Jakarta III ethics committee. Thanks to Director of Health Polytechnics Ministry of health Jakarta III for funding this research, Head of Duren Sawit Hospital East Jakarta for research

\section{REFERENCES}

[1] Riset Kesehatan dasar. Badan Penelitian dan Pengembangan Kesehatan. Kementerian Kesehatan, 2013

[2] Beck, R.W. Mental Health and Psychiatric Nursing A Holistic Life Cycle Approach. Third ed. Mosby Company 1993

[3] Rasmun, Keperawatan Kesehatan Mental Psikiatri terintergrasi dengan Keluarga. Sagung seto. 2001

[4] Kementerian Kesehatan Indonesia Republik Indonesia. Profil Kesehatan Indonesia 2012. Jakarta: Kementerian Kesehatan Republik Indonesia. 2014.

[5] Sari. R.N. Pengaruh komunikasi terapeutik terhadap kemampuan mengendalikan marah pasien. Sagung Seto 2014.

[6] Fitria, Nita. Buku Ajar Keperawatan Jiwa. Salemba Medika.2009 
[7] Yosep Iyus. Mental Nursing. Refika Aditama. Bandung 2007

[8] Maramis, W.F. Catatan Ilmu Kedokteran Jiwa.Airlangga University Press.1995

[9] Friedman, Marilyn M. Buku Ajar keperawatan Keluarga. Riset, Teori, Praktek. Jakarta. EGC. 2010

[10] Carson, V.B. Mental Health Nursing: The nurse - patient journey 2nd ed Philadelphia; WB. Saunders Company

[11] Armiyadi.M. 19. Armiyadi.M. Milieu therapy how to implement it in Aceh Mental Hospital, di akses tanggal23September2017darihttps://brage.bibsys.no/xmlui/bitstream/handle/11250/132574/Armiyadi.pdf?seque nce $=1 \&$ is Allowed $=y$

[12] Stuart, W Gail. Principles and Practice of Psychiatric Nursing, 9 ed Evolve 2005

[13] Stuart, Gail and Laraia. Buku Saku Keperawatan Jiwa edisi 3 , EGC Jakarta. 2005

[14] Soetjiningsih. Tumbuh Kembang Remaja dan Permasalahannya. Jakarta. Sagung Seto, 2010 